\title{
Herbicide Glyphosate: Toxicity and Microbial Degradation
}

\author{
Simranjeet Singh ${ }^{1,2,3,+\oplus \mathbb{D} \text {, Vijay Kumar }}{ }^{4,+}{ }^{\mathbb{D}}$, Jatinder Pal Kaur Gill ${ }^{5,+}$, Shivika Datta ${ }^{6,+}$, \\ Satyender Singh ${ }^{3,+}$, Vaishali Dhaka ${ }^{1}{ }^{\circ}$, Dhriti Kapoor ${ }^{7}$, Abdul Basit Wani ${ }^{8}{ }^{\circledR}$, \\ Daljeet Singh Dhanjal ${ }^{1}{ }^{\circledR}$, Manoj Kumar ${ }^{9} \mathbb{D}$, S. L. Harikumar ${ }^{9}$ and Joginder Singh ${ }^{1, *(\mathbb{C}}$ \\ 1 Department of Biotechnology, Lovely Professional University, Phagwara 144411, India; \\ simnav14@gmail.com (S.S.); dhakavaishali@gmail.com (V.D.); daljeetdhanjal92@gmail.com (D.S.D.) \\ 2 Punjab Biotechnology Incubator (PBTI), Phase-V, S.A.S. Nagar, Punjab 160059, India \\ 3 Regional Advance Water Testing Laboratory, Department of Water Supply and Sanitation, Phase-II, \\ S.A.S. Nagar 160054, India; satyenderjamwal@gmail.com \\ 4 Regional Ayurveda Research Institute for Drug Development, Gwalior 474009, India; \\ vkumar8491@gmail.com \\ 5 Department of Education, Adelaide, SA 5000, Australia; jpkaur015@gmail.com \\ 6 Department of Zoology, Doaba College Jalandhar, Jalandhar 144001, India; shivikadatta@gmail.com \\ 7 Department of Botany, Lovely Professional University, Phagwara 144411, India; dhriti.21851@lpu.co.in \\ 8 Department of Chemistry, Lovely Professional University, Phagwara 144411, India; basitwani81@gmail.com \\ 9 Department of Life Sciences, Central University Jharkhand, Brambe, Ranchi 835205, India; \\ manoj@cuj.ac.in (M.K.); slharikumar@gmail.com (S.L.H.) \\ * Correspondence: joginder.15005@lpu.co.in; Tel.: +91-8872-487-264 \\ + Equal Contribution.
}

Received: 27 August 2020; Accepted: 13 October 2020; Published: 15 October 2020

\begin{abstract}
Glyphosate is a non-specific organophosphate pesticide, which finds widespread application in shielding crops against the weeds. Its high solubility in hydrophilic solvents, especially water and high mobility allows the rapid leaching of the glyphosate into the soil leading to contamination of groundwater and accumulation into the plant tissues, therefore intricating the elimination of the herbicides. Despite the widespread application, only a few percentages of the total applied glyphosate serve the actual purpose, dispensing the rest in the environment, thus resulting in reduced crop yields, low quality agricultural products, deteriorating soil fertility, contributing to water pollution, and consequently threatening human and animal life. This review gives an insight into the toxicological effects of the herbicide glyphosate and current approaches to track and identify trace amounts of this agrochemical along with its biodegradability and possible remediating strategies. Efforts have also been made to summarize the biodegradation mechanisms and catabolic enzymes involved in glyphosate metabolism.
\end{abstract}

Keywords: herbicide; glyphosate; toxicity; environmental fate; biodegradation; catabolic enzymes

\section{Introduction}

Glyphosate [N-(phosphonomethyl) glycine CAS\#1071-83-6] is one of the most extensively used broad-spectrum organophosphorus herbicides [1]. It is a widely used herbicide in agriculture against perennial and annual weeds and in silviculture, domestic gardens, and urban areas [2]. It is an essential component of non-selective and post-emergent herbicides used to protect the crop from grasses, annual broad-leaved weeds, woody plants, etc. [3]. The parent compound was firstly sold in 1974 under the trade name "Roundup" by Monsanto [4]. This compound tends to be a zwitterion, in which phosphonic hydrogen detaches and joins the amine group. Glyphosate was first synthesized by Henri 
Martin while working at Cilag (a Swiss pharmaceutical company), but J.E. Franzo in 1970 conducted the herbicidal test on this compound and commercialized it in 1974 [5]. The potential mode of action of glyphosate makes it an herbicide of interest. The global glyphosate market was $\$ 23.97$ billion in 2016 , and at a growth rate of $6.05 \%$ for the forecasting period, it is estimated to reach $\$ 34.10$ billion in 2022 [6].

Glyphosate is the only herbicide that targets 5-enolpyruvylshikimate-3-phosphate synthase (EPSPS) without any available analog and obstructs the aromatic amino acid biosynthesis in the shikimate pathway [7]. Inhibition of EPSPS by glyphosate retards the synthesis of essential secondary metabolites and proteins; additionally, it curbs the vital energy pathways in soil microbes and plants [8]. A study reveals that glyphosate alters the soil texture and microbial diversity by reducing the microbial richness and increasing the population of phytopathogenic fungi [9]. This herbicide is considered safer than others, but its overuse imposes chronic effects on the environment and humans [10]. Moreover, its broad herbicidal activities and the development of transgenic glyphosate-resistant crops (e.g., cotton, canola, maize, and soybean) are the main reasons for the excess use of this herbicide [11]. Unawareness regarding the use of this herbicide has led to its accumulation in both terrestrial and aquatic ecosystems [12]. As glyphosate can be absorbed by soil particles, it often remains at the vadose zone [4]. Hence, it is usually detected in surface water, water-sediment interface from surface run-off, and groundwater [13].

The International Agency for Research on Cancer (IARC) classified glyphosate as "Category 2a," which specifies probable carcinogenic to humans [14]. The United States Environmental Protection Agency (USEPA) classifies this herbicide as "Group E carcinogen," which means non-cancerous for humans [4]. In contrast to the European Food Safety Authority, which determines glyphosate as a potent carcinogen for humans, but the experimental evidence does not support this determination [4], even though traces of glyphosate have been detected in human urine samples, highlighting its persistence, bioaccumulation, and potential health risk [15]. Although glyphosate residual concentrations have never crossed over the threshold level, its harmful effects cannot be ignored [16]. A study reveals that this herbicide alters the soil texture and microbial diversity by reducing the microbial richness and increasing the population of phytopathogenic fungi [17]. Literature has proved that glyphosate is among the carcinogenic compounds and can cause organ failure by inhibiting acetylcholinesterase and inducing oxidative stress in non-mammalian species [9]. Aminomethylphosphonic acid (AMPA) is the keystone metabolite of glyphosate often found in the sediment, surface, and groundwater [4]. Various in vitro toxicity studies have disclosed that AMPA affects human red blood cells and can lead to chromosomal aberrations in fish [18].

Degradation of glyphosate can be achieved using abiotic and biotic means, e.g., absorption, photolysis, thermolysis, and biodegradation with catabolic enzymes. Lately, a blend of photocatalyst with UV light has come in the limelight for their ability to treat pollutants like pesticides. The photocatalytic degradation can break glyphosate down to non-toxic compounds like $\mathrm{CO}_{2}$, water, and inorganic ions [4]. This mechanism depends on the photocatalytic oxidation reaction triggered by highly reactive oxidation and hydroxyl radical [19]. The benefits of photocatalysis comprise cost-effectiveness, stability, and non-toxicity, whereas its manipulation in situ is a critical disadvantage. This degradation method proved to be optimal for removing glyphosate in sewage treatment [10]. An eco-friendly strategy like bioremediation would be another promising alternative to overcome the environmental and health risks derived from glyphosate and its residues. Therefore, it has become essential to study glyphosate biodegradation driven by microbial degraders. Numerous studies have revealed microbial capacity as a robust and useful tool in bioremediation. However, previously published literature fails to comprehend the mechanisms and pathways by which different microbial species can degrade glyphosate. This review aims to outline the ecotoxicity of glyphosate and its biodegradation via the roles of catabolic enzymes. 


\section{Glyphosate Toxicity}

\subsection{Ecotoxicity}

The intensive use of glyphosate has led to the contamination of different ecosystems adversely affecting animals, plants, and microorganisms, which further leads to the deterioration of food chains. The pesticide residues often remain in the food chain, and diet contains nutritional deficiencies, especially vitamins and minerals and has the capability to incur systemic toxicity. Some studies revealed that glyphosate is becoming a major issue in the growth of chronic diseases. Glyphosate strongly disrupts soil biology as it is toxic to beneficial microflora and earthworms. Being a potent inhibitor of EPSPS in the shikimic acid pathway, it exerts adverse effects on non-target aquatic plants, which are a great environmental concern (Figure 1). The functional characterization of the plants is also affected by glyphosate as PGPRs play a vital role in the production of auxin and siderophores, solubilization of phosphate, and zinc uptake which convert insoluble forms of macronutrient elements into soluble forms.
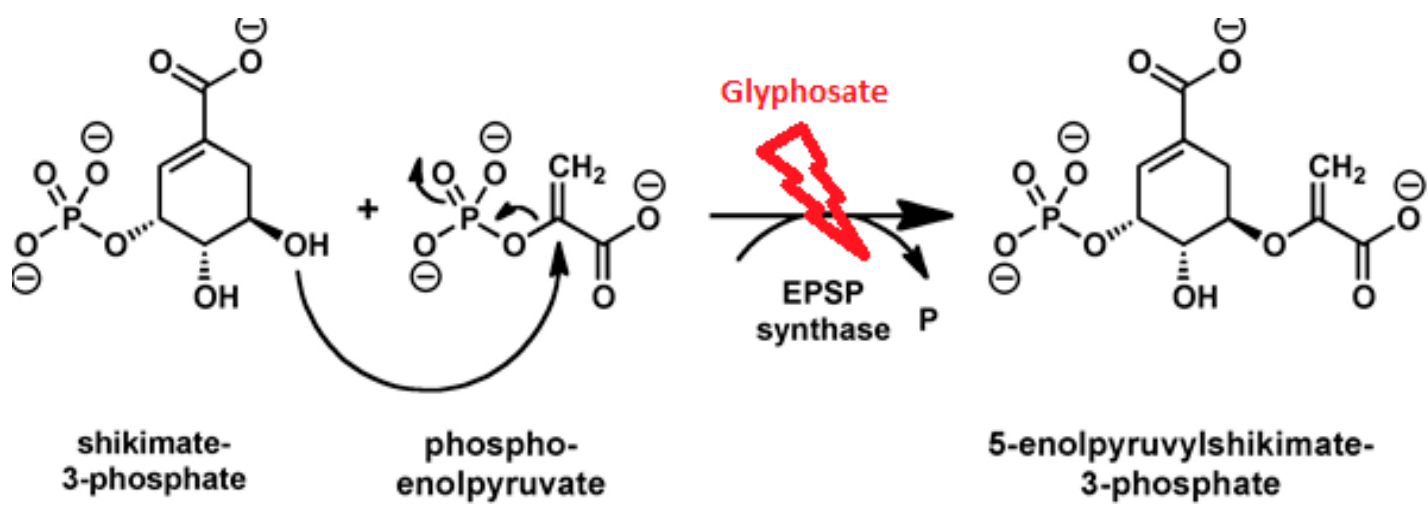

Figure 1. Schematic representation of binding of glyphosate to the substrate-binding site of the EnolPyruvylShikimate-3-Phosphate Synthase (EPSPS), inhibiting its activity, and blocking its importation into the chloroplast.

The United States environmental protection agency (USEPA) considers glyphosate in toxicity class-IV for inhalation and also reports its relatively low oral and dermal acute toxicity [4]. It can cause irritation, vomiting, nausea, and photo contact dermatitis [20]. It is slightly toxic for amphibians and fishes. It is excreted in urine and feces [4]. It is less persistent in water and has a half-life of 12 days to 70 days [21]. It is reported to bio-accumulate in animals and has the ability to break down considerably depending on the particular environment [4].

Glyphosate alters several plant physiological aspects due to its herbicidal appearance. A number of off-target plants species have been studied so far to evaluate the adverse effects of glyphosate, viz., Zea mays, Oryza sativa, Tritium aestivum, and Pisum sativum [22-26]. Various physiological processes in the plants show the negative impacts of glyphosate toxicity including oxidative burst, drop in the synthesis of chlorophyll [26-28], hampered photosynthetic rate, alteration in the level of plant hormones, reduced nitrogen assimilation, decreased nutritional content, disturbances in lignin and carbon metabolism [23]. It affects photosynthetic activity indirectly by obstructing the synthesis of pigments and fatty acids, decreasing the stomatal conductance, and declined the availability of PSII-associated metals and amino acids, which ultimately reduces its ability to transfer photo-chemical energy into the electron transport chain [24]. Oxidative stress caused by glyphosate is due to the overaccumulation of reactive oxygen species (ROS) and disturbance in the mineral nutrients level. It inhibits the EPSPS enzyme, which ultimately blocks the shikimate pathway and results in inhibiting the biosynthesis of plant secondary metabolites [29]. It also alters the nitrogen metabolism by affecting the rhizobial symbiont or indirectly by altering the physiology of the host genotypes [30]. As a metal 
chelator, glyphosate declines level of vital nutrients having key roles as enzymatic co-factors and biomolecular constituents (Figure 2).

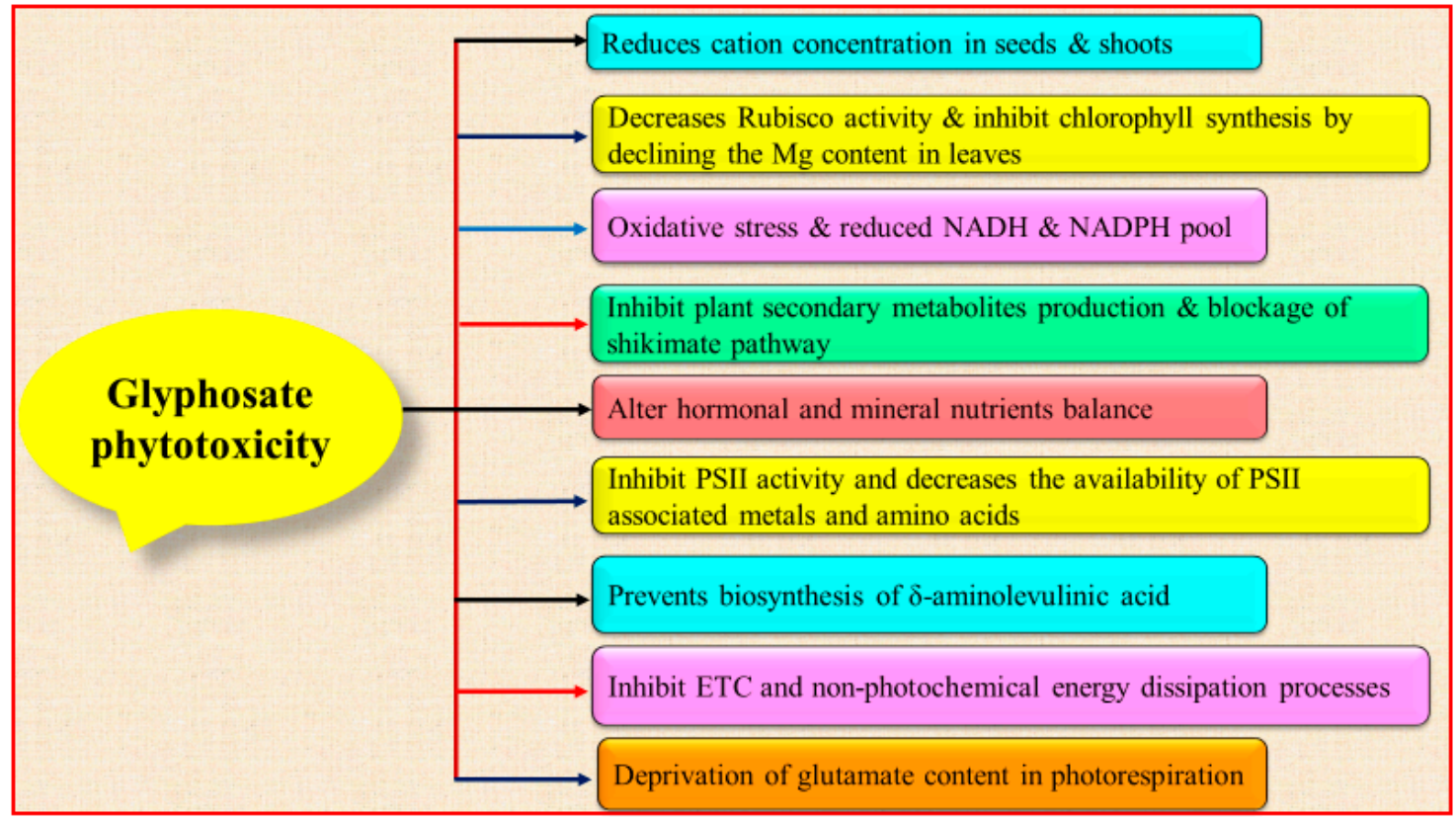

Figure 2. Glyphosate toxicity mediated alteration in the various physicochemical functions of plants (NADH $=$ Nicotinamide adenine dinucleotide hydrogen NADPH $=$ Nicotinamide adenine dinucleotide phosphate, $\mathrm{PSII}=$ Photosystem II, ETC = Electron Transport Chain).

Production of quinone (a secondary metabolite and an integral part of various biochemical processes), chlorophyll, fatty acids, and amino acids is inhibited as an aftermath of its overuse [30-32]. Reduction in chlorophyll level and hence the photosynthetic efficiency are attributed to inhibition in the amount of $\mathrm{Mg}$ in leaves [30] along with that of Fe leading to the prevention of biosynthesis of significant chlorophyll enzymes biosynthetic pathway like catalase, peroxidase and $\delta$-aminolevulinic acids [33]. Working of enzymes- ascorbate peroxidase (APX), catalase (CAT), and polyamine (PA) in Lemna minor tissues is also hampered by glyphosate-containing herbicides [34]. Glyphosate also competes with amino acid glycine resulting in loss of glutamate or with a principal product of alanine synthetase active site hindering the synthesis of alanine in $\mathrm{C}_{2}$ cycle/photorespiration [35].

An assessment of glyphosate's spray retention, uptake by leaves and its translocation in Ambrosia artemisiifolia revealed that it translocates to the growing apical tissues through the roots quite rapidly almost within three hours [36]. Accessibility of amino acids, as well as metal ions related to the PSI and PSII to the transmission of light energy into the cyclic and non-cyclic electron transport chain systems, is notably depleted by glyphosate [37]. $\mathrm{CO}_{2}$ assimilation potential of plants by a reduction in net carbon exchange and stomatal conductance get adversely affected by foliar spray of glyphosate and its metabolites [29,38]. Improper functioning of enzyme Rubisco owing to the dropping down of levels of ribulose-1,5-biphosphate (RuBP) and 3-phosphoglyceric acid (PGA) in the Calvin cycle is also linked to glyphosate toxicity [39].

Physiological efficiency of the host plant is dwindled by glyphosate via indirectly disturbing the nitrogen metabolism or directly harming the symbiotic rhizobial bacteria present in the soil [29] due to which stoppage of growth and ultimately death may occur [39]. Further studies showed a reduction in nodule formation and nitrogen fixation process by the incessant use of this very herbicide [30]. Induction of nutritional distress in plants is another harmful upshot of glyphosate, arising because of the latter's interference with the location mechanism of nutrients. Reports suggest that obstructions are appearing in the shikimate pathway cause oxidative stress by inhibition of particular target sites 
of the plants in which oxidative stress markers are seen to undergo changes in their nature [23]. Morphological and operational expertise exhibited by plants is also put at stake by glyphosate because of decline in lignin content [40]. Suppression of EPSPS and reduced availability of cinnamate precursors contribute significantly towards lowering down of the extent of lignin synthesis [41]. Hormonal balance in Glycine max gets distressed due to glyphosate, which in turn mar its growth and development features [42]. Blockage of the shikimate pathway, which arrests the auxin synthesis from its indolic precursor tryptophan, is likewise found to be associated with glyphosate. Harmful impacts of glyphosate use on algae have also been affirmed through estimation of measured environment concentrations (MEC) and the $\mathrm{EC}_{50}$ value of glyphosate in Scenedesmus quadricauda, which turned out to be $0.1 \mu \mathrm{g} / \mathrm{L}$ and $4.4 \mathrm{mg} / \mathrm{L}$, respectively [43].

The noxious effects of herbicides are not only limited to unicellular organisms but also in multicellular organisms [4]. Right from the lower invertebrates up to higher chordates, all the animals are found to be affected by this herbicide. Invertebrates like earthworms are majorly affected as determined by some parameters like a reduced rate of reproduction, loss of biomass, DNA damage and reduced casting activity [44-46]. Glyphosate and its formulation Roundup were used for toxicity evaluation on two different populations of Daphnia magna (one population was taken from laboratory cultures and other was wild-collected species). Roundup showed acute toxicity values after $48 \mathrm{~h}$ in the range $560-1700 \mu \mathrm{g} / \mathrm{mL}$. The wild species was found to be twice more sensitive towards Roundup than glyphosate. However, the standard species depicted Roundup being 35 times more toxic than glyphosate [47]. Gaur and Bhargava [48] reported acute toxicity to zebrafish embryos exposed to glyphosate concentration at $50 \mu \mathrm{g} / \mathrm{mL}$ and above. Developmental toxicity was characterized by physical malformations in zebrafish embryos such as yolk sac edema, pericardial edema, eye defects body bending, etc. The $\mathrm{LD}_{50}$ for glyphosate was reported $66.04 \pm 4.6 \mu \mathrm{g} / \mathrm{mL}$ after $48 \mathrm{~h}$ of exposure [48]. There is also a report that glyphosate adversely affects the spermatozoa of the honey bee. After exposure of glyphosate for $40 \mathrm{~min}, \mathrm{LD}_{50}$ concentration was found to be $0.31 \mathrm{mg} / \mathrm{mL}(p<0.0001)$. The lethal time $\left(\mathrm{LT}_{50}\right)$ at $0.05 \mathrm{mg} / \mathrm{mL}$ concentration of glyphosate was found to be $468 \mathrm{~min}(p=0.009)$ [49]. The effect of herbicide, glyphosate on Wistar rats was evaluated in a $28 \mathrm{~d}$ study. Daily dose equivalent to 0.1 acceptable operator exposure level (AOEL) and 0.5 consumer acceptable daily intake (ADI) was considered for evaluation. The treated animals weighed less in comparison to control. Treatment groups had significant primary DNA damage in the liver cells and leukocytes. Acetylcholinesterase (AChE) activity was found to be inhibited with all the treatments suggesting that even low doses of glyphosate exposure can cause serious adverse effects [50]. Glyphosate undergoes one-compartment model with an elimination rate constant of $K_{\mathrm{el}}=0.021 \mathrm{~h}^{-1}$ when $100 \mathrm{mg} / \mathrm{kg} \mathrm{bw}$ ) of glyphosate concentrations in plasma in Sprague-Dawley rats [51].

The leaching of glyphosate in aquatic systems reduced the egg-laying capacity and hampered the hatching process in many aquatic animals like sea urchins and snails [52]. Apart from lower organisms, glyphosate is also known to exert toxic effects on humans. It is a potential endocrine disruptor in human beings which causes serious damage to the placenta [52]. It is also genotoxic and causes plasma damage and epithelial cell damage in humans. Hepatic, embryonic and placental cell lines are known to be affected largely by this herbicide. It affects almost the entire animal kingdom. It affects the food chain and causes undesired changes that impose serious concern.

The presence of glyphosate in food, water, and air confirms that it is ingested frequently and found in human urine at levels around $110 \mu \mathrm{g} / \mathrm{L}$ [13]. AMPA and glyphosate itself are the major metabolites detected in human urine samples $[15,53,54]$. The maximum contamination level (MCL) of glyphosate is reported to be $700 \mu \mathrm{g} / \mathrm{L}$ in the USA (EPA 2015) and $1000 \mu \mathrm{g} / \mathrm{L}$ in Australia [55]. In Europe, the tolerable risk is reported to be $77 \mu \mathrm{g} / \mathrm{L}$ [56] while the acceptable concentration in drinking water is less than $0.1 \mu \mathrm{g} / \mathrm{L}$. 


\subsection{Cytotoxicity and Genotoxicity}

The study of Roundup on human cell cultures depicts an increase in Cytochrome P 450 (CYP 450) activity [57]. The formulation (Roundup) was reported to cause problems during pregnancy as confirmed by exposing the JEG3 (human placental cell line). The study also reported the inhibition of aromatase enzymes and fluctuated mRNA [58]. The effect of Roundup Ultra 360 SL, along with glyphosate on human erythrocytes, depicted the elevation in the level of methaemoglobin and hemolysis but showed no significant change in GSH (glutathione level) [59]. Glyphosate exposure is also reported to cause arrhythmia, hypotension, mental relapse, and renal and respiratory failure in humans [60]. A cytotoxic effect like membrane damage as well as impaired mitochondrial function, which may lead to cancer on the treatment of dosage less than $40 \mathrm{mg} / \mathrm{L}$ to buccal epithelial cell line TR146. However, on the dose of $>80 \mathrm{mg} / \mathrm{L}$, elevated lactate dehydrogenase (LDH), leading to membrane and DNA damage, was observed [61]. The intoxication of glyphosate is reported to cause cardiovascular shock, hemodynamic hindrance, intravascular coagulation, myocardial infarction and multiple organ failure [62]. In vivo glyphosate toxicity assessment over HepG2 (hepatic cell line) revealed the disruption of an androgen receptor (MDA-MB453-kb2) and termination of the transcription cycle of estrogen receptor of HepG2 at $0.5 \mathrm{ppm}$. At $5 \mathrm{ppm}$, further DNA damage was observed, and at 10 ppm concentration, it included cytotoxic effects as well [57]. Glyphosate based herbicides (GlyBH) have been reported to cause chronic effects such as hepatorenal, teratogenic, and tumorigenic effects along with endocrine functionality disruption [14]. Amendment in estrogen response element, which further alters the ER $\alpha$ and ER $\beta$ expression up to 513-fold was reported by Thongprakaisang and coworkers [63]. The effect of glyphosate $(0.36 \mathrm{mg} / \mathrm{L})$ was investigated on sperm motility and sperm DNA fragmentation. It was found out that $1 \mathrm{~h}$ post-treatment, the sperm motility was significantly reduced in comparison to respective control although sperm DNA fragmentation was not significantly different in the first hour [64]. A decrease in peripheral blood mononuclear cells (PBMCs) viability by $2.7 \%$ was observed after incubation with glyphosate $(19 \mathrm{mM})$ for $24 \mathrm{~h}$ [65]. Glyphosate exposure decreases cell viability depending on concentration and time exposure in human epithelial type 2 cell line (HEP -2) [66]. Glyphosate levels of 1 and 10 exposed to the blood-brain barrier (BBB) in vitro based on induced pluripotent stem cells (iPSCs) depicted an increase in the permeability across BBB [67]. Glyphosate and AMPA concentrations up to $50 \mathrm{mM}$ were observed to inhibit cell growth in eight cancer cell lines, including four prostate cancer (C4-2B, LNCaP, DU-145, and PC-3), two ovarian cancer (SKOV-3 and OVCAR-3), one cervical HeLa, and one lung cancer cell line (A549) [68]. Hoppin et al. [69] reported the association of glyphosate with atopic asthma. However, Henneberger and associates [70] found an inverse association between glyphosate and asthma symptoms depicting that patients with asthma may be less sensitive to glyphosate.

\section{Microbial Degradation of Glyphosate}

Extensive and unrestricted applications of glyphosate threatened the health of humans, animals, non-target plants, and microbial flora in various ecosystems. Several studies have scrutinized the effect of glyphosate on carbon mineralization. There are three major intermediates of glyphosate metabolism, AMPA, acetyl-glyphosate, and sarcosine, which get further degraded via different metabolic pathways. The primary metabolite of glyphosate is AMPA. It causes secondary contamination in the environment because of the non-feasibility of intracellular degradation. Some studies have shown that glyphosate can ominously increase microbial respiration for the short term, which typically happens from 7 to 38 days. Other studies have specified that glyphosate has no effect on microbial respiration.

Various studies have been reported on the degradation of glyphosate and its metabolites in different environmental matrices (Achromobacter sp. MPK 7A, Comamonas odontotermitis P2, Ochrobactrum intermedium Sq20, and Pseudomonas sp. 4ASW) in contaminated niches via enrichment approach [71-74]. Microbial species such as Arthrobacter atrocyaneus ATCC 13752, Alcaligenes sp. GL, Arthrobacter sp. GLP-1, Geobacillus caldoxylosilyticus T20, and Pseudomonas sp. PG2982 were reported to consume glyphosate as a nutrient for their growth [75-79]. From the list of glyphosate-degrading 
microbes, including actinomycetes, bacteria, fungi, and microcytes, the bacteria hold the primary position $[16,80,81]$. Thus, to assess the glyphosate-degrading ability of microbes for their application in bioremediation, the optimization of the growth conditions like $\mathrm{pH}$, temperature, incubation time, inoculum, and glyphosate concentration is necessary. The results obtained from response surface methodology (RSM) revealed that bacteria are effective in degrading glyphosate when grown under optimum conditions [73,82]. Arthrobacter sp. GLP-1, Alcaligenes sp. GL, Pseudomonas pseudomallei 22, and Flavobacterium sp.GD1 utilize glyphosate as a phosphorus source $[75,79,83,84]$.

In the same way, Ochrobactrum intermedium strain Sq20, Agrobacterium radiobacter strain SW9, and Achromobacter sp. strain LW9 use glyphosate as nitrogen or carbon source $[74,85]$. Various fungal populations like Aspergillus oryzae A-F02, Aspergillus niger, Penicillium IIR, Mucor IIIR, Trichoderma harzianum, Scopulariopsis sp., and Penicillium notatum utilize glyphosate as sole phosphorus source [80,86-89]. Moreover, several strains of microbes utilize glyphosate as a different type of energy source like Arthrobacter sp. GLP-1/Nit-1 [90], Comamonas odontotermitis P2, and Streptomycete sp. StC, which decompose glyphosate for sole nitrogen, sole phosphorus, and both nitrogen and phosphorus source, respectively [73,81]. Another Arthrobacter species, Arthrobacter atrocyaneus ATCC 13,752, has been reported to rapidly degrade AMPA and glyphosate without enrichment technique [78]. Another bacterial species, Flavobacterium sp. GD1, uses AMPA and glyphosate solely as a phosphorus source. Moreover, it has been found that Pi (inorganic phosphorus) concentration does not affect the metabolism of glyphosate, but it suppresses the process of AMPA degradation [79]. Inhibition via Pi has been observed in various bacterial isolates such as Pseudomonas sp. GLC11 and Pseudomonas sp. PG2982, using phosphorus moiety of glyphosate [76,91-93].

To date, there are only three chief intermediates of glyphosate metabolism such as AMPA. Acetyl-glyphosate and sarcosine have been found to get further degraded via different metabolic pathways. AMPA is the primary and major metabolite of glyphosate degradation pathway. Due to the non-feasibility of intracellular degradation of AMPA, it becomes the source of secondary contamination in the environment $[75,83,94]$. The strains that have been known to utilize AMPA as sole Pi source include Pseudomonas sp. 4ASW, Pseudomonas sp. LBr, Bacillus megaterium 2BLW, and Pseudomonas sp. [94,95]. 7B. In contrast to AMPA pathway, the bacterial isolates also degrade glyphosate to sarcosine and use sarcosine as a growth nutrient. Few reports enlighten on the bacterial isolates like Bacillus cereus CB4, Ochrobactrum anthropi GPK 3, and Pseudomonas sp. LBr, which robustly degrade glyphosate to AMPA as well as sarcosine $[82,94,96]$. Thus, bacterial strains showing the potential of degrading glyphosate emerged as the bioremediation tool for remediating the contaminated environment. On the sequence analysis of C-P lyase (carbon-phosphorus lyase) and glyphosate oxidoreductase genes, it was discovered that both pathways operate in parallel in Comamonas odontotermitis P2 [97]. In one of the metabolic processes, glyphosate gets converted into acetylglyphosate but is not further degraded by the Achromobacter sp. $\mathrm{Kg} 16$ to use it as a phosphorus source. Unpredictably, the same bacterial isolate degrades glyphosate to AMPA when a carbon source is absent in the culture medium [72].

\section{Degradation Kinetics and Glyphosate Residues}

Glyphosate is a common herbicide used worldwide, having the capability of rapid degradation in soils, particularly by microbial processes. AMPA is the most commonly produced degraded product of glyphosate in water and soil. Tazdaït and coworkers [98] determined glyphosate residues by colorimetric method and at $570 \mathrm{~nm}$ absorbance. They also determined the percentage of glyphosate removal by using the following formula:

$$
\text { Percent glyphosate removal }=\mathrm{C}_{\mathrm{i}}-\mathrm{C}_{\mathrm{f}} / \mathrm{C}_{\mathrm{f}} \times 100
$$

where $C_{i}$ and $C_{f}$ are the glyphosate concentrations values at times 0 and $t$, respectively.

Various kinetic models and adsorption isotherms were found best fit to the biodegradation kinetics of glyphosate like Andrews [99], Aiba et al. [100], Han and Levenspiel [101], Luong [102], Tessier [99], 
Webb [99], Tseng and Wayman [103], and Yano and Koga [104]. However, from the biodegradation point of view, pseudo order kinetics was the best fit model for degradation studies. Biodegradation rate can be determined by using pseudo-first-order kinetics as reported in our previous studies showing $85-90 \%$ of glyphosate with half-life periods from 8.36 to 9.12 days with major metabolites included glycine, AMPA, sarcosine, glyoxylate, metaphosphoric acid, and phosphate [105]. The equation below correspond to the equations of the concentration variation of glyphosate with time plotted ( $t$ ) on the basis of the linear regression results obtained by plotting Time (in days) vs. Log Ct (in ppm).

$$
\begin{gathered}
\mathrm{d}[\mathrm{C}] / \mathrm{dt}=-\mathrm{k}_{\text {obs }}[\mathrm{C}] \\
\log [\mathrm{C}] /[\mathrm{C}]_{0}=\mathrm{k}_{\mathrm{obs}} \mathrm{t} \\
\mathrm{t}_{1 / 2}=\left(1 / \mathrm{k}_{\text {obs }}\right) \times \log 2
\end{gathered}
$$

where, $[C]=$ glyphosate concentration at time $t(\mathrm{ppm}) ;[C]_{0}=$ the initial glyphosate concentration $(\mathrm{ppm}) ; \mathrm{k}_{\mathrm{obs}}=$ the pseudo-first-order constant $\left(\mathrm{day}^{-1}\right)$ which is equal to slope of line, i.e., $\mathrm{k}_{\mathrm{obs}}=-$ slope.

\section{Mechanism Underlying Bio-Degradation}

Glyphosate can be easily degraded by two metabolic pathways, i.e., AMPA and sarcosine via glyphosate degrading bacteria. This is achieved by (a) oxidase, which degrades the carboxymethylene -nitrogen bond of glyphosate and converts it into AMPA and glyoxylate and/or (b) C-P lyase, which directly cleaves the carbon-phosphorus bond to produce sarcosine. Both degradation pathways use C-P lyase to cleave the C-P bond of AMPA compound.

The primary step involved in glyphosate degradation pathway is the catalytic action of glyphosate oxidoreductase, which synthesizes the glyoxylate and AMPA. Pseudomonas sp. LBr degrades the glyphosate through AMPA and glycine pathway, and on NMR analysis, it was found that it uses formaldehyde and glyoxylate for its development [94]. Another bacterial strain, Arthrobacter atrocyaneus ATCC 13,752 degrades glyphosate into AMPA and then finally to $\mathrm{CO}_{2}$, but $\mathrm{CO}_{2}$ obtained was not the by-product of AMPA [90]. The AMPA, an intermediate metabolite, gets liberated into the ecosystem or further degrades via different enzymes $[78,94,96]$. Generally, AMPA act as a substrate for enzyme C-P lyase, converting it to $\mathrm{P}_{\mathrm{i}}$ and methylamine for phosphorus uptake for Arthrobacter sp. GLP-1, Arthrobacter atrocyaneus ATCC 13752, and Pseudomonas sp. LBr [71,78,106]. Lately, Ochrobactrum anthropi GPK3 isolate illustrated the new AMPA degradation pathway in which AMPA is first degraded to phosphonoformaldehyde via transaminase enzyme and then further to formaldehyde via phosphonatase (Figure 3).

Another glyphosate degradation pathway involves C-P lyase and leads to the synthesis of $\mathrm{P}_{\mathrm{i}}$ and sarcosine, for example, Pseudomonas sp. PG2982 metabolizes glyphosate via C-P lyase and produces sarcosine, which further gets degraded to formaldehyde and glycine by the action of sarcosine oxidase [91]. It has been found that Arthrobacter sp. GLP-1 uses glycine for the protein synthesis by stimulating the formation of amino acids (serine and threonine) and peptide backbone [78]. This fate of glyphosate metabolites has been noticeably assessed with the help of isotope labelling. 


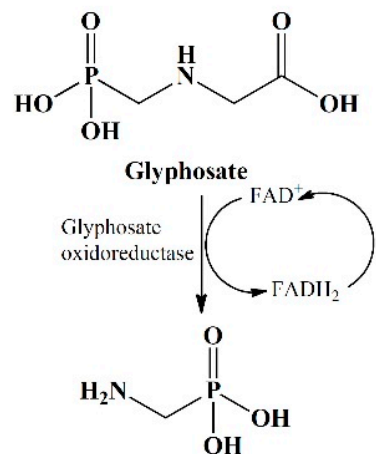

Aminomethylphosphonic acid

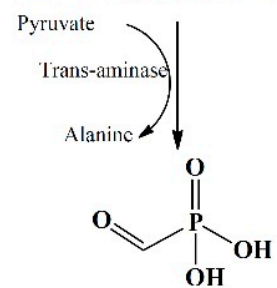

phosphonoformaldehyde

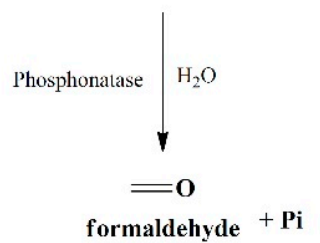

Figure 3. Glyphosate bio-degradation pathway via Aminomethylphosphonic acid (AMPA) and formaldehyde formation.

\section{Enzymatic Mediated Metabolism of Glyphosate}

Glyphosate oxidoreductase (GOX) is responsible for the degradation of glyphosate to AMPA by cleaving the $\mathrm{C}-\mathrm{N}$ bond in bacterial species [4]. On screening the sequence of Comamonas odontotermitis P2(KX980206.1), Ochrobactrum anthropi GPK3, and Ochrobactrum sp. G1 (GU214711.1), it has a similarity index of $99 \%$ similarity with the GOX-encoding genes. Hence, the synthetic construct between GOX gene (HQ110097.1) and GOX (ADV58259.1) has been developed so that it can be used for developing a transgenic glyphosate-tolerant variety of canola [97,107]. However, GOX enzyme (purified) obtained from microbes or synthesized by expressing the gox gene in expression vector shows the low affinity towards glyphosate $[108,109]$. Ochrobactrum anthropi GPK 3 producing GOX enzyme containing flavin adenine dinucleotide (FAD) confirms its relation with flavin monooxygenase superfamily [15]. glpA and glpB, are the two ORFs (Open reading frames) in Pseudomonas pseudomallei 22, which are related to glyphosate metabolism. glpA provides tolerance against glyphosate, and glpB is linked with the degradation of glyphosate to AMPA [84].

Enzymes like C-P lyase, phosphoenolpyruvate hydrolase phosphonoacetatehydrolase, and phosphonoacetaldehyde hydrolase have been reported in the lysis of C-P bond of glyphosate [110], where C-P lyase disintegrates the glyphosate C-P bond while remaining are site-specific with their substrate, C-P bond of glyphosate being hydrolytically stable and highly resistant to photolysis and chemolysis. Only C-P lyase has a high affinity for glyphosate which breaks the C-P bond (inactive form) resulting in the formation of sarcosine. Therefore, C-P lyase complex has been extensively studied in E. coli. In E. coli, this complex is formed by the product of 14 operon genes (phn CDEFGHIJKLMNOP), which are related to Pho regulon. In accordance with previous biochemical and genetical studies, it has been confirmed that $p h n \mathrm{CDE}$ encodes for transporter protein of ATP-binding cassette, and $p h n \mathrm{~F}$ encodes for repressor protein [111-113], while seven proteins (phnG-I; K-M) are considered to be 
encoding for core components of C-P lyase (membrane-bound), which are involved in degrading phosphonates into phosphate, except phn which acts as the catalyst $[113,114]$.

Furthermore, $p h n$ NOP performs the accessory and regulatory function in catabolic degradation pathway involving C-P lyase, whereas pure and well-characterized C-P lyase cannot degrade the C-P bond of glyphosate. Until now, C-P lyase, having a high affinity towards glyphosate, has not been characterized at the molecular level. Moreover, we have found another C-P lyase which is non-specific to glyphosate but is involved in the C-P bond cleavages during the degradation of AMPA. This evidence proves that one bacterium probably has two co-existing C-P lyases having varied substrate specificity $[113,114]$. The detailed enzyme-mediated biodegradation of glyphosate has been outlined in Figure 4.
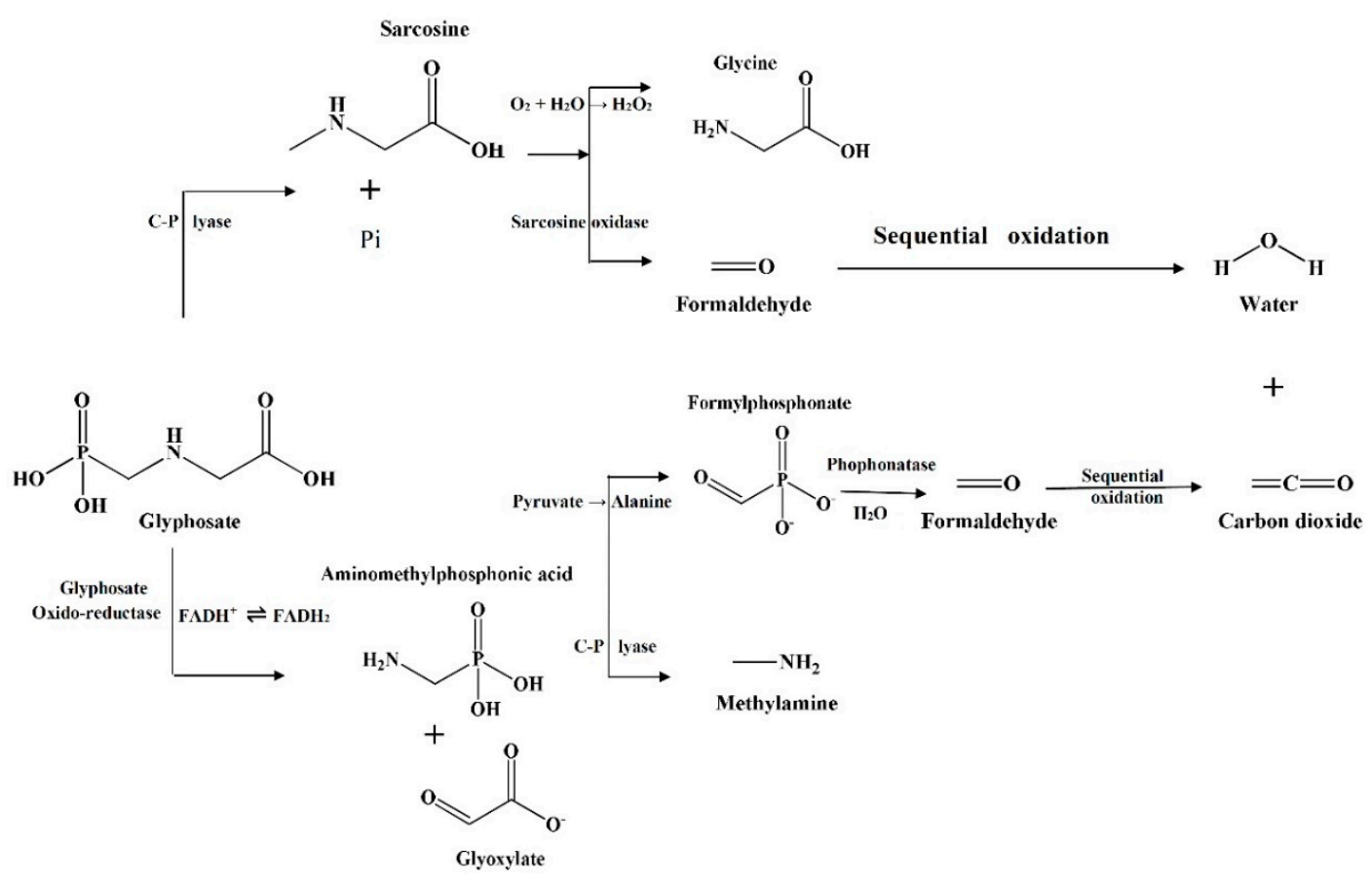

Figure 4. Enzyme mediated biodegradation of glyphosate.

Usually, glyphosate metabolism for AMPA synthesis is not dependent on $\mathrm{P}_{\mathrm{i}}$ concentration, excluding Arthrobacter atrocyaneus ATCC 13752, as $P_{i}$ represses the degradation of glyphosate [78]. $\mathrm{P}_{\mathrm{i}}$ concentration regulates the metabolic conversion of glyphosate to sarcosine, e.g., repression of glyphosate degradation was observed in Arthrobacter sp. and Pseudomonas sp. 4ASW in the presence of $P_{i}[71,106]$. Their glyphosate transporter system revealed that they are dependent on $P_{i}$ level. Additionally, biochemical and molecular studies revealed that C-P lyase is regulated by phn genes, which gets up-regulated during the absence of $\mathrm{P}_{\mathrm{i}}$. Along with that, the role of the two-component system (PhoR-PhoB) and their responses to the endogenous and exogenous $P_{i}$ concentration have been studied in E. coli. Hence, it can be stated that the $P_{\mathrm{i}}$ level hinders the sarcosine pathway of glyphosate metabolism $[114,115]$. Table 1 outlines various microbial species responsible for glyphosate metabolism and enzymes responsible for degradation processes. 
Table 1. A list of various microbial species responsible for glyphosate metabolism and enzymes responsible for degradation processes.

\begin{tabular}{|c|c|c|c|c|c|}
\hline Microbial Species & Source & Enzymes/Gene & Location & $\begin{array}{c}\text { Metabolites after } \\
\text { Degradation }\end{array}$ & References \\
\hline Ochrobactrum anthropi GDOS & Soil & - & Iran & AMPA & [16] \\
\hline Pseudomonas sp. 4ASW & Soil & - & UK & Sarcosine & [71] \\
\hline Comamonas odontotermitis P2 & Soil & $\begin{array}{c}\text { Glyphosate } \\
\text { oxidoreductase }\end{array}$ & Pakistan & - & [73] \\
\hline Alcaligenes sp. GL & Selective medium & - & Germany & $\begin{array}{l}\text { AMPA (5\%) and } \\
\text { sarcosine }(95 \%)\end{array}$ & [75] \\
\hline Pseudomonas sp. PG298231 & Mixed culture & $\begin{array}{l}\text { C-P lyase, sarcosine } \\
\text { oxidase }\end{array}$ & Louisiana & Sarcosine & [76] \\
\hline $\begin{array}{l}\text { Geobacillus caldoxylosilyticus T20, } \\
\text { Ochrobactrum anthropi LBAA }\end{array}$ & Soil & & UK & AMPA & [77] \\
\hline $\begin{array}{c}\text { Arthrobacter atrocyaneus } \\
\text { ATCC } 13752\end{array}$ & Microbial collection & C-P lyase & Germany & AMPA & [78] \\
\hline Arthrobacter sp. GLP-1 & Selective medium & - & USA & Sarcosine & [79] \\
\hline Penicillium notatum & $\begin{array}{l}\text { Mutation of the wild } \\
\text { type }\end{array}$ & - & Poland & AMPA & [80] \\
\hline Streptomyces sp. StC & Sludge & - & Poland & Sarcosine & [81] \\
\hline Bacillus cereus CB4 & Soil & - & China & $\begin{array}{l}\text { AMPA, glyoxylate, } \\
\text { sarcosine, glycine and } \\
\text { formaldehyde }\end{array}$ & [82] \\
\hline Flavobacterium sp. GD1 & Sludge & - & Missouri & AMPA & [83] \\
\hline Pseudomonas pseudomallei & Soil & glpA and glpB & USA & AMPA & [84] \\
\hline $\begin{array}{c}\text { Achromobacter sp., Rhizobium } \\
\text { radiobacter }\end{array}$ & Sludge & - & USA & AMPA & [85] \\
\hline Aspergillus oryzae A-F02 & Soil & - & China & AMPA and methylamine & [86] \\
\hline $\begin{array}{c}\text { Aspergillus niger, } \\
\text { Scopulariopsis sp., Trichoderma } \\
\text { harzianum }\end{array}$ & Soil & - & Poland & AMPA & [88] \\
\hline Pseudomonas sp. LBr & Sludge & $\begin{array}{c}\text { Glyphosate } \\
\text { oxidoreductase and C-P } \\
\text { lyase }\end{array}$ & Missouri & AMPA $(95 \%)$, sarcosine $(5 \%)$ & [94] \\
\hline $\begin{array}{l}\text { Achromobacter sp. MPS } 12 \mathrm{~A}, \\
\text { Ochrobactrum anthropi GPK } 3\end{array}$ & Soil & sarcosine oxidase & Russia & $\begin{array}{l}\text { Sacrosine } \\
\text { AMPA }\end{array}$ & [96] \\
\hline $\begin{array}{c}\text { Bacillus subtilis, Rhizobium } \\
\text { leguminosarum, Streptomyces sp. }\end{array}$ & Soil & $\begin{array}{c}\text { C-P lyase and } \\
\text { glyphosate oxidoreductase }\end{array}$ & India & AMPA and methylamine & [105] \\
\hline $\begin{array}{l}\text { Fusarium oxysporum, Trichoderma } \\
\text { viridae, Aspergillus niger }\end{array}$ & Soil & - & Nigeria & AMPA and sarcosine & [116] \\
\hline Trichoderma viride Strain FRP 3 & Soil & - & Indonesia & - & [117] \\
\hline $\begin{array}{l}\text { Aspergillus section Flavi and } \\
\text { Aspergillus niger }\end{array}$ & - & - & Argentina & - & [118] \\
\hline Ochrobactrum anthropi S5 & Soil & - & USA & AMPA & [119] \\
\hline Rhizobium meliloti 1021 & $\begin{array}{l}\text { Mutation of the wild } \\
\text { strain }\end{array}$ & sarcosine oxidase & Massachusetts & Sarcosine & [120] \\
\hline Salinicoccus sp. & Soil & - & Iran & AMPA & [121] \\
\hline $\begin{array}{l}\text { Ochrobactrum anthropi GPK } 3, \\
\text { Achromobacter sp. } 16 \mathrm{~kg}\end{array}$ & Soil & $\begin{array}{c}\text { Glyphosate } \\
\text { oxidoreductase } \\
\text { transaminase enzyme and } \\
\text { phosphonatase }\end{array}$ & Russia & - & [122] \\
\hline Agrobacterium radiobacter & Wastewater & - & US & Putatively sarcosine & [123] \\
\hline Nocardia mediterranie THS 1 & - & - & India & AMPA & [124] \\
\hline
\end{tabular}

\section{Conclusions}

The review portrays that there is much more to be learned about the fate of glyphosate, including its sorption, degradation, and leaching. The fate depends upon the medium and varies a lot from soil to soil as well. This variability does not give a clear prediction, and results generate ambiguous conclusions. Apart from environmental risks, glyphosate is also associated with health risks. This makes for the requirement to develop an eco-friendly strategy for bioremediation. Glyphosate being a potent inhibitor of EPSPS in the shikimic pathway, exerts negative effects on non-target plants. Various ecosystems and their abiotic and biotic components including animals, plants, and microbes are adversely affected by the indiscriminate use of glyphosate. Right from unicellular to multicellular and lower to higher invertebrates, glyphosate affects all the animals from the kingdom. Right from the 
lower invertebrates up to higher chordates, all the animals are found to be affected by this herbicide. Glyphosate can actually be degraded via two metabolic pathways-AMPA and sarcosine through glyphosate degrading bacteria. Soil organic matter also indirectly affect the sorption of glyphosate. The phosphate in soil competes with glyphosate for sorption, which ultimately affects the retention and degradation of glyphosate. The pre-sorption of phosphates almost eliminates the chances of glyphosate sorption in some soils. Though in some soils the availability of phosphate is found to accelerate the degradation of glyphosate. There is still more to it, and this gap needs to be studied further. The fate of glyphosate should be considered for studies as it is primary for environmental and health risk assessments. For optimal use of glyphosate, social costs, in addition to direct costs, should also be taken under consideration. Glyphosate is found to be an absolutely effective herbicide and should be considered for the development of new cost-effective herbicides for sustainable agriculture. There is no question that glyphosate resistant crops make glyphosate the most inexpensive and effective technology for weed management. But after its advent, with time, its effectiveness decreased and the mineral nutrition was also altered due to the capability of glyphosate to chelate with metal ions. Certain additives may be used to enhance the biological performance of glyphosate. A better understanding of glyphosate action and usage of adjuvants for overall better effect should be other approaches to designing future glyphosate formulations. There is still more to it, and this gap needs to be studied further.

Author Contributions: Conceptualization, S.S. (Simranjeet Singh) and J.S.; methodology, J.P.K.G., S.S. (Simranjeet Singh), M.K., S.L.H. and V.K.; validation, J.S., D.K. and S.S. (Satyender Singh); investigation, S.D., S.S. (Simranjeet Singh) and D.S.D.; resources, J.S. and A.B.W.; writing-original draft preparation, S.S. (Simranjeet Singh), V.K., A.B.W, S.D., M.K., S.L.H. and D.K.; writing-review and editing, S.S. (Simranjeet Singh), V.D. and J.S.; supervision, J.S. All authors have read and agreed to the published version of the manuscript.

Funding: This research received no external funding.

Conflicts of Interest: The authors declare no conflict of interest.

\section{References}

1. Gill, J.P.K.; Sethi, N.; Mohan, A. Analysis of the glyphosate herbicide in water, soil and food using derivatising agents. Environ. Chem. Lett. 2017, 15, 85-100. [CrossRef]

2. Zhang, C.; Hu, X.; Luo, J.; Wu, Z.; Wang, L.; Li, B.; Wang, Y.; Sun, G. Degradation dynamics of glyphosate in different types of citrus orchard soils in China. Molecules 2015, 20, 1161-1175. [CrossRef]

3. Conrad, A.; Schröter-Kermani, C.; Hoppe, H.W.; Rüther, M.; Pieper, S.; Kolossa-Gehring, M. Glyphosate in German adults-Time trend (2001 to 2015) of human exposure to a widely used herbicide. Int. J. Hyg. Environ. Health 2017, 220, 8-16. [CrossRef]

4. Singh, S.; Kumar, V.; Datta, S.; Wani, A.B.; Dhanjal, D.S.; Romero, R.; Singh, J. Glyphosate uptake, translocation, resistance emergence in crops, analytical monitoring, toxicity and degradation: A review. Environ. Chem. Lett. 2020, 18, 663-702. [CrossRef]

5. Duke, S.O.; Powles, S.B. Glyphosate: A once-in-a-century herbicide. In Proceedings of the Pest Management Science; John Wiley \& Sons, Ltd: Hoboken, NJ, USA, 2008; Volume 64, pp. 319-325.

6. Dill, G.M. Glyphosate-resistant crops: History, status and future. In Proceedings of the Pest Management Science; John Wiley \& Sons, Ltd: Hoboken, NJ, USA, 2005; Volume 61, pp. 219-224.

7. Haslam, E. The Shikimate Pathway: Biosynthesis of Natural Products Series; Butterworths: London, UK, 2014.

8. Sviridov, A.V.; Shushkova, T.V.; Ermakova, I.T.; Ivanova, E.V.; Epiktetov, D.O.; Leont'evskii, A.A. Microbial degradation of glyphosate herbicides (review). Prikl. Biokhim. Mikrobiol. 2015, 51, 183-190. [PubMed]

9. Hadi, F.; Mousavi, A.; Noghabi, K.A.; Tabar, H.G.; Salmanian, A.H. New bacterial strain of the genus Ochrobactrum with glyphosate-degrading activity. J. Environ. Sci. Health-Part B Pestic. Food Contam. Agric. Wastes 2013, 48, 208-213. [CrossRef]

10. Wang, S.; Seiwert, B.; Kästner, M.; Miltner, A.; Schäffer, A.; Reemtsma, T.; Yang, Q.; Nowak, K.M. (Bio)degradation of glyphosate in water-sediment microcosms-A stable isotope co-labeling approach. Water Res. 2016, 99, 91-100. [CrossRef] [PubMed] 
11. Annett, R.; Habibi, H.R.; Hontela, A. Impact of glyphosate and glyphosate-based herbicides on the freshwater environment. J. Appl. Toxicol. 2014, 34, 458-479. [CrossRef]

12. Hanke, I.; Wittmer, I.; Bischofberger, S.; Stamm, C.; Singer, H. Relevance of urban glyphosate use for surface water quality. Chemosphere 2010, 81, 422-429. [CrossRef]

13. Shushkova, T.; Ermakova, I.; Leontievsky, A. Glyphosate bioavailability in soil. Biodegradation 2010, 21, 403-410. [CrossRef]

14. International Agency for Research on Cancer. Some Organophosphate Insecticides and Herbicides. IARC Monographs on the Evaluation of Carcinogenic Risks to Humans; International Agency for Research on Cancer: Lyon, France, 2017; Volume 112, pp. 1-452.

15. Niemann, L.; Sieke, C.; Pfeil, R.; Solecki, R. A critical review of glyphosate findings in human urine samples and comparison with the exposure of operators and consumers. J. Verbrauch. Leb. 2015, 10, 3-12. [CrossRef]

16. Mesnage, R.; Defarge, N.; Spiroux de Vendômois, J.; Séralini, G.E. Potential toxic effects of glyphosate and its commercial formulations below regulatory limits. Food Chem. Toxicol. 2015, 84, 133-153. [CrossRef] [PubMed]

17. Zhan, H.; Feng, Y.; Fan, X.; Chen, S. Recent advances in glyphosate biodegradation. Appl. Microbiol. Biotechnol. 2018, 102, 5033-5043. [CrossRef]

18. Grandcoin, A.; Piel, S.; Baurès, E. AminoMethylPhosphonic acid (AMPA) in natural waters: Its sources, behavior and environmental fate. Water Res. 2017, 117, 187-197. [CrossRef]

19. Xu, X.; Ji, F.; Fan, Z.; He, L. Degradation of glyphosate in soil photocatalyzed by $\mathrm{Fe}_{3} \mathrm{O}_{4} / \mathrm{SiO}_{2} / \mathrm{TiO}_{2}$ under solar light. Int. J. Environ. Res. Public Health 2011, 8, 1258-1270. [CrossRef] [PubMed]

20. Fang, S.C.; Rodrigues, E.G.; Christiani, D.C. Environmental Health Hazards in the Tropics. In Hunter's Tropical Medicine and Emerging Infectious Diseases; Ryan, E.T., Hill, D.R., Solomon, T., Aronson, N.E., Endy, T.P., Eds.; Elsevier: Amsterdam, The Netherlands, 2020; pp. 200-208.

21. Chandrasekera, W.U.; Weeratunga, N.P. The lethal impacts of Roundup®(glyphosate) on the fingerlings of guppy, Poecilia reticulata Peters, 1859. Asian Fish. Sci. 2011, 24, 367-378.

22. Zablotowicz, R.M.; Reddy, K.N. Nitrogenase activity, nitrogen content, and yield responses to glyphosate in glyphosate-resistant soybean. Crop Prot. 2007, 26, 370-376. [CrossRef]

23. Ahsan, N.; Lee, D.G.; Lee, K.W.; Alam, I.; Lee, S.H.; Bahk, J.D.; Lee, B.H. Glyphosate-induced oxidative stress in rice leaves revealed by proteomic approach. Plant Physiol. Biochem. 2008, 46, 1062-1070. [CrossRef]

24. Miteva, L.P.E.; Ivanov, S.V.; Alexieva, V.S. Alterations in glutathione pool and some related enzymes in leaves and roots of pea plants treated with the herbicide glyphosate. Russ. J. Plant Physiol. 2010, 57, 131-136. [CrossRef]

25. Orcaray, L.; Zulet, A.; Zabalza, A.; Royuela, M. Impairment of carbon metabolism induced by the herbicide glyphosate. J. Plant Physiol. 2012, 169, 27-33. [CrossRef]

26. Zabalza, A.; Orcaray, L.; Fernández-Escalada, M.; Zulet-González, A.; Royuela, M. The pattern of shikimate pathway and phenylpropanoids after inhibition by glyphosate or quinate feeding in pea roots. Pestic. Biochem. Physiol. 2017, 141, 96-102. [CrossRef] [PubMed]

27. Reddy, K.N.; Rimando, A.M.; Duke, S.O. Aminomethylphosphonic acid, a metabolite of glyphosate, causes injury in glyphosate-treated, glyphosate-resistant soybean. J. Agric. Food Chem. 2004, 52, 5139-5143. [CrossRef] [PubMed]

28. Serra, A.-A.; Nuttens, A.; Larvor, V.; Renault, D.; Couée, I.; Sulmon, C.; Gouesbet, G. Low environmentally relevant levels of bioactive xenobiotics and associated degradation products cause cryptic perturbations of metabolism and molecular stress responses in Arabidopsis thaliana. J. Exp. Bot. 2013, 64, 2753-2766. [CrossRef]

29. Zobiole, L.H.S.; Kremer, R.J.; Oliveira, R.S.; Constantin, J. Glyphosate affects microorganisms in rhizospheres of glyphosate-resistant soybeans. J. Appl. Microbiol. 2011, 110, 118-127. [CrossRef]

30. Zobiole, L.H.S.; Oliveira, R.S.; Kremer, R.J.; Constantin, J.; Yamada, T.; Castro, C.; Oliveira, F.A.; Oliveira, A. Effect of glyphosate on symbiotic $\mathrm{N}_{2}$ fixation and nickel concentration in glyphosate-resistant soybeans. Appl. Soil Ecol. 2010, 44, 176-180. [CrossRef]

31. Yanniccari, M.; Tambussi, E.; Istilart, C.; Castro, A.M. Glyphosate effects on gas exchange and chlorophyll fluorescence responses of two Lolium perenne L. biotypes with differential herbicide sensitivity. Plant Physiol. Biochem. 2012, 57, 210-217. [CrossRef] 
32. Gomes, M.P.; Maccario, S.; Le Manac'h, S.G.; Lucotte, M.; Moingt, M.; Paquet, S.; Labrecque, M.; Juneau, P. Comments on the "Glyphosate herbicide residue determination in samples of environmental importance using spectrophotometric method". J. Hazard. Mater. 2017, 340, 487-489. [CrossRef] [PubMed]

33. Marsh, H.V.; Evans, H.J.; Matrone, G. Investigations of the Role of Iron in Chlorophyll Metabolism. II. Effect of Iron Deficiency on Chlorophyll Synthesis. Plant Physiol. 1963, 38, 638-642. [CrossRef] [PubMed]

34. Mkandawire, M.; Teixeira Da Silva, J.A.; Dudel, E.G. The lemna bioassay: Contemporary issues as the most standardized plant bioassay for aquatic ecotoxicology. Crit. Rev. Environ. Sci. Technol. 2014, 44, 154-197. [CrossRef]

35. Vivancos, P.D.; Driscoll, S.P.; Bulman, C.A.; Ying, L.; Emami, K.; Treumann, A.; Mauve, C.; Noctor, G.; Foyer, C.H. Perturbations of amino acidmetabolism associated with glyphosate-dependent inhibition of shikimic acid metabolism affect cellular redox homeostasis and alter the abundance of proteins involved in photosynthesis and photorespiration. Plant Physiol. 2011, 157, 256-268. [CrossRef]

36. Hussain, S.; Siddique, T.; Arshad, M.; Saleem, M. Bioremediation and phytoremediation of pesticides: Recent advances. Crit. Rev. Environ. Sci. Technol. 2009, 39, 843-907. [CrossRef]

37. Cakmak, I.; Yazici, A.; Tutus, Y.; Ozturk, L. Glyphosate reduced seed and leaf concentrations of calcium, manganese, magnesium, and iron in non-glyphosate resistant soybean. Eur. J. Agron. 2009, 31, 114-119. [CrossRef]

38. Ding, W.; Reddy, K.N.; Zablotowicz, R.M.; Bellaloui, N.; Arnold Bruns, H. Physiological responses of glyphosate-resistant and glyphosate-sensitive soybean to aminomethylphosphonic acid, a metabolite of glyphosate. Chemosphere 2011, 83, 593-598. [CrossRef]

39. De María, N.; Becerril, J.M.; García-Plazaola, J.I.; Hernández, A.; De Felipe, M.R.; Fernández-Pascual, M. New insights on glyphosate mode of action in nodular metabolism: Role of shikimate accumulation. J. Agric. Food Chem. 2006, 54, 2621-2628. [CrossRef] [PubMed]

40. Bonga, J.M. Clonal Propagation of Mature Trees: Problems and Possible Solutions. In Cell and Tissue Culture in Forestry; Springer: Dordrecht, The Netherlands, 1987; pp. 249-271.

41. Marchiosi, R.; Ferrarese, M.D.L.L.; Bonini, E.A.; Fernandes, N.G.; Ferro, A.P.; Ferrarese-Filho, O. Glyphosate-induced metabolic changes in susceptible and glyphosate-resistant soybean (Glycine max L.) roots. Pest. Biochem. Physiol. 2009, 93, 28-33. [CrossRef]

42. Sugano, S.; Sugimoto, T.; Takatsuji, H.; Jiang, C.J. Induction of resistance to Phytophthora sojae in soyabean (Glycine max) by salicylic acid and ethylene. Plant Pathol. 2013, 62, 1048-1056. [CrossRef]

43. Guo, J.; Boxall, A.; Selby, K. Do pharmaceuticals pose a threat to primary producers? Crit. Rev. Environ. Sci. Technol. 2015, 45, 2565-2610. [CrossRef]

44. Helander, M.; Saloniemi, I.; Omacini, M.; Druille, M.; Salminen, J.P.; Saikkonen, K. Glyphosate decreases mycorrhizal colonization and affects plant-soil feedback. Sci. Total Environ. 2018, 642, 285-291. [CrossRef] [PubMed]

45. Muangphra, P.; Kwankua, W.; Gooneratne, R. Genotoxic effects of glyphosate or paraquat on earthworm coelomocytes. Environ. Toxicol. 2014, 29, 612-620. [CrossRef]

46. Pochron, S.; Simon, L.; Mirza, A.; Littleton, A.; Sahebzada, F.; Yudell, M. Glyphosate but not Roundup®harms earthworms (Eisenia fetida). Chemosphere 2020, 241, 125017. [CrossRef]

47. Székács, I.; Fejes, Á.; Klátyik, S.; Takács, E.; Patkó, D.; Pomóthy, J.; Mörtl, M.; Horváth, R.; Madarász, E.; Darvas, B.; et al. Environmental and toxicological impacts of glyphosate with its formulating adjuvant. Int. J. Biol. Vet. Agric. Food Eng. 2014, 8, 212-218.

48. Gaur, H.; Bhargava, A. Investigation of Toxicity Induced by Chemicals and Their Mechanisms Using Zebrafish Vertebrate Animal Model. Ph.D. Dissertation, Indian Institute of Technology Hyderabad, Telangana, India, 2019.

49. Hoopman, A.; North, H.; Rajamohan, A.; Bowsher, J. Toxicity assessment of glyphosate on honey bee (Apis mellifera) spermatozoa [abstract]. In Proceedings of the Society for Integrative \& Comparative Biology (SCIB) Annual Meeting, San Francisco, CA, USA, 3-7 January 2018; pp. 3-7.

50. Bernal, J.; Bernal, J.L.; Martin, M.T.; Nozal, M.J.; Anadón, A.; Martínez-Larrañaga, M.R.; Martínez, M.A. Development and validation of a liquid chromatography-fluorescence-mass spectrometry method to measure glyphosate and aminomethylphosphonic acid in rat plasma. J. Chromatogr. B 2010, 878, 3290-3296. [CrossRef] 
51. Milić, M.; Žunec, S.; Micek, V.; Kašuba, V.; Mikolić, A.; Tariba Lovaković, B.; Živković Semren, T.; Pavičić, I.; Marjanović Čermak, A.M.; Pizent, A.; et al. Oxidative stress, cholinesterase activity, and DNA damage in the liver, whole blood, and plasma of Wistar rats following a 28-day exposure to glyphosate. Arhiv za Higijenu Rada i Toksikologiju 2018, 69, 154-168. [CrossRef]

52. Gill, J.P.K.; Sethi, N.; Mohan, A.; Datta, S.; Girdhar, M. Glyphosate toxicity for animals. Environ. Chem. Lett. 2018, 16, 401-426. [CrossRef]

53. Connolly, A.; Leahy, M.; Jones, K.; Kenny, L.; Coggins, M.A. Glyphosate in Irish adults—A pilot study in 2017. Environ. Res. 2018, 165, 235-236. [CrossRef]

54. Soukup, S.T.; Merz, B.; Bub, A.; Hoffmann, I.; Watzl, B.; Steinberg, P.; Kulling, S.E. Glyphosate and AMPA levels in human urine samples and their correlation with food consumption: Results of the cross-sectional KarMeN study in Germany. Arch. Toxicol. 2020, 94, 1575. [CrossRef] [PubMed]

55. Australian Drinking Water Guidelines 6. 2011. Available online: http://www.clearwater.asn.au/user-data/.../ Aust_drinking_water_guidelines (accessed on 23 February 2015).

56. Horth, H.; Blackmore, K. Survey of Glyphosate and AMPA in Groundwaters and Surface Waters in Europe; No: UC8073.02; WRc plc: Swindon, UK, 2009.

57. Gasnier, C.; Dumont, C.; Benachour, N.; Clair, E.; Chagnon, M.C.; Séralini, G.E. Glyphosate-based herbicides are toxic and endocrine disruptors in human cell lines. Toxicology 2009, 262, 184-191. [CrossRef]

58. Richard, S.; Moslemi, S.; Sipahutar, H.; Benachour, N.; Seralini, G.E. Differential effects of glyphosate and Roundup on human placental cells and aromatase. Environ. Health Perspect. 2005, 113, 716-720. [CrossRef]

59. Pieniażek, D.; Bukowska, B.; Duda, W. Comparison of the effect of Roundup Ultra 360 SL pesticide and its active compound glyphosate on human erythrocytes. Pestic. Biochem. Physiol. 2004, 79, 58-63. [CrossRef]

60. Seok, S.J.; Park, J.S.; Hong, J.R.; Gil, H.W.; Yang, J.O.; Lee, E.Y.; Song, H.Y.; Hong, S.Y. Surfactant volume is an essential element in human toxicity in acute glyphosate herbicide intoxication. Clin. Toxicol. 2011, 49, 892-899. [CrossRef]

61. Koller, V.J.; Fürhacker, M.; Nersesyan, A.; Mišík, M.; Eisenbauer, M.; Knasmueller, S. Cytotoxic and DNA-damaging properties of glyphosate and Roundup in human-derived buccal epithelial cells. Arch. Toxicol. 2012, 86, 805-813. [CrossRef]

62. Zouaoui, K.; Dulaurent, S.; Gaulier, J.M.; Moesch, C.; Lachâtre, G. Determination of glyphosate and AMPA in blood and urine from humans: About 13 cases of acute intoxication. Forensic Sci. Int. 2013, 226, e20-e25. [CrossRef]

63. Thongprakaisang, S.; Thiantanawat, A.; Rangkadilok, N.; Suriyo, T.; Satayavivad, J. Glyphosate induces human breast cancer cells growth via estrogen receptors. Food Chem. Toxicol. 2013, 59, 129-136. [CrossRef] [PubMed]

64. Anifandis, G.; Katsanaki, K.; Lagodonti, G.; Messini, C.; Simopoulou, M.; Dafopoulos, K.; Daponte, A. The effect of glyphosate on human sperm motility and sperm DNA fragmentation. Inter. J. Environ. Res. Public Health 2018, 15, 1117. [CrossRef] [PubMed]

65. Kwiatkowska, M.; Huras, B.; Bukowska, B. The effect of metabolites and impurities of glyphosate on human erythrocytes (in vitro). Pestic. Biochem. Physiol. 2014, 109, 34-43. [CrossRef]

66. Coalova, I.; de Molina, M.D.C.R.; Chaufan, G. Influence of the spray adjuvant on the toxicity effects of a glyphosate formulation. Toxicol. Vitro 2014, 28, 1306-1311. [CrossRef]

67. Martinez, A.; Al-Ahmad, A.J. Effects of glyphosate and aminomethylphosphonic acid on an isogeneic model of the human blood-brain barrier. Toxicol. Lett. 2019, 304, 39-49. [CrossRef]

68. Li, Q.; Lambrechts, M.J.; Zhang, Q.; Liu, S.; Ge, D.; Yin, R.; Xi, M.; You, Z. Glyphosate and AMPA inhibit cancer cell growth through inhibiting intracellular glycine synthesis. Drug Des. Dev. Ther. 2013, 7, 635.

69. Hoppin, J.A.; Valcin, M.; Henneberger, P.K.; Kullman, G.J.; Umbach, D.M.; London, S.J.; Alavanja, M.C.; Sandler, D.P. Pesticide use and chronic bronchitis among farmers in the Agricultural Health Study. Am. J. Ind. Med. 2007, 50, 969-979. [CrossRef] [PubMed]

70. Henneberger, P.K.; Liang, X.; London, S.J.; Umbach, D.M.; Sandler, D.P.; Hoppin, J.A. Exacerbation of Symptoms in Agricultural Pesticide Applicators with Asthma. Int. Arch. Occup. Environ. Health 2014, 87, 423-432. [CrossRef] [PubMed]

71. Dick, R.E.; Quinn, J.P. Control of glyphosate uptake and metabolism in Pseudomonas sp. 4ASW. FEMS Microbiol. Lett. 1995, 134, 177-182. [CrossRef] 
72. Ermakova, I.T.; Shushkova, T.V.; Sviridov, A.V.; Zelenkova, N.F.; Vinokurova, N.G.; Baskunov, B.P.; Leontievsky, A.A. Organophosphonates utilization by soil strains of Ochrobactrum anthropi and Achromobacter sp. Arch. Microbiol. 2017, 199, 665-675. [CrossRef] [PubMed]

73. Firdous, S.; Iqbal, S.; Anwar, S. Optimization and Modeling of Glyphosate Biodegradation by a Novel Comamonas odontotermitis P2 through Response Surface Methodology. Pedosphere 2017. [CrossRef]

74. Firdous, S.; Iqbal, S.; Anwar, S.; Jabeen, H. Identification and analysis of 5-enolpyruvylshikimate-3-phosphate synthase (EPSPS) gene from glyphosate-resistant Ochrobactrum intermedium Sq20. Pest Manag. Sci. 2018, 74, 1184-1196. [CrossRef]

75. Lerbs, W.; Stock, M.; Parthier, B. Physiological aspects of glyphosate degradation in Alcaligenes spec. strain GL. Arch. Microbiol. 1990, 153, 146-150. [CrossRef]

76. Moore, J.K.; Braymer, H.D.; Larson, A.D. Isolation of a Pseudomonas sp. which utilizes the phosphonate herbicide glyphosate. Appl. Environ. Microbiol. 1983, 46, 316-320. [CrossRef]

77. Obojska, A.; Ternan, N.G.; Lejczak, B.; Kafarski, P.; McMullan, G. Organophosphonate utilization by the thermophile GeoBacillus caldoxylosilyticus T20. Appl. Environ. Microbiol. 2002, 68, 2081-2084. [CrossRef]

78. Pipke, R.; Amrhein, N. Degradation of the phosphonate herbicide glyphosate by Arthrobacter atrocyaneus ATCC 13752. Appl. Environ. Microbiol. 1988, 54, 1293-1296. [CrossRef] [PubMed]

79. Pipke, R.; Amrhein, N.; Jacob, G.S.; Schaefer, J.; Kishore, G.M. Metabolism of glyphosate in an Arthrobacter sp. GLP-1. Eur. J. Biochem. 1987, 165, 267-273. [CrossRef] [PubMed]

80. Bujacz, E.; Wieczorek, P.; Krzys, T.; Goła, Z.; Lejczak, B.; Kavfarski, P. Organophosphonate Utilization by the Wild-Type Strain of Penicillium notatum. Appl. Environ. Microbiol. 1995, 61, 2905-2910. [CrossRef]

81. Obojska, A.; Lejczak, B.; Kubrak, M. Degradation of phosphonates by Streptomycete isolates. Appl. Microbiol. Biotechnol. 1999, 51, 872-876. [CrossRef] [PubMed]

82. Fan, J.; Yang, G.; Zhao, H.; Shi, G.; Geng, Y.; Hou, T.; Tao, K. Isolation, identification and characterization of a glyphosate-degrading bacterium, Bacillus cereus CB4, from soil. J. Gen. Appl. Microbiol. 2012, 58, 263-271. [CrossRef]

83. Balthazor, T.M.; Hallas, L.E. Glyphosate-degrading microorganisms from industrial activated sludge. Appl. Environ. Microbiol. 1986, 51, 432-434. [CrossRef] [PubMed]

84. Penaloza-Vazquez, A.; Mena, G.L.; Herrera-Estrella, L.; Bailey, A.M. Cloning and sequencing of the genes involved in glyphosate utilization by Pseudomonas pseudomallei. Appl. Environ. Microbiol. 1995, 61, 538-543. [CrossRef]

85. McAuliffe, K.S.; Hallas, L.E.; Kulpa, C.F. Glyphosate degradation by Agrobacterium radiobacter isolated from activated sludge. J. Ind. Microbiol. 1990, 6, 219-221. [CrossRef]

86. Fu, G.-M.; Chen, Y.; Li, R.-Y.; Yuan, X.-Q.; Liu, C.M.; Li, B.; Wan, Y. Pathway and rate-limiting step of glyphosate degradation by Aspergillus oryzae A-F02. Prep. Biochem. Biotechnol. 2017, 47, 782-788. [CrossRef] [PubMed]

87. Klimek, M.; Lejczak, B.; Kafarski, P.; Forlani, G. Metabolism of the phosphonate herbicide glyphosate by a non-nitrate-utilizing strain of Penicilliumchrysogenum. Pest Manag. Sci. 2001, 57, 815-821. [CrossRef]

88. Krzyśko-Łupicka, T.; Orlik, A. Use of glyphosate as the sole source of phosphorus or carbon for the selection of soil-borne fungal strains capable to degrade this herbicide. Chemosphere 1997, 34, 2601-2605. [CrossRef]

89. Krzyśko-Lupicka, T.; Strof, W.; Kubś, K.; Skorupa, M.; Wieczorek, P.; Lejczak, B.; Kafarski, P. The ability of soil-borne fungi to degrade organophosphonate carbon-to-phosphorus bonds. Appl. Microbiol. Biotechnol. 1997, 48, 549-552. [CrossRef]

90. Pipke, R.; Amrhein, N. Isolation and Characterization of a Mutant of Arthrobacter sp. Strain GLP-1 Which Utilizes the Herbicide Glyphosate as Its Sole Source of Phosphorus and Nitrogen. Appl. Environ. Microbiol. 1988, 54, 2868-2870. [CrossRef]

91. Kishore, G.M.; Jacob, G.S. Degradation of glyphosate by Pseudomonas sp. PG2982 via a sarcosine intermediate. J. Biol. Chem. 1987, 262, 12164-12168. [PubMed]

92. Selvapandiyan, A.; Bhatnagar, R.K. Isolation of a glyphosate-metabolising Pseudomonas: Detection, partial purification and localisation of carbon-phosphorus lyase. Appl. Microbiol. Biotechnol. 1994, 40, 876-882. [CrossRef]

93. Shinabarger, D.L.; Braymer, H.D. Glyphosate catabolism by Pseudomonas sp. strain PG2982. J. Bacteriol. 1986, 168, 702-707. [CrossRef] [PubMed] 
94. Jacob, G.S.; Garbow, J.R.; Hallas, L.E.; Kimack, N.M.; Kishore, G.M.; Schaeffer, J. Metabolism of glyophosate in Pseudomonas sp. strain LBr. Appl. Environ. Microbiol. 1988, 54, 2953-2958. [CrossRef] [PubMed]

95. Quinn, J.P.; Peden, J.M.M.; Dick, R.E. Carbon-phosphorus bond cleavage by Gram-positive and Gram-negative soil bacteria. Appl. Microbiol. Biotechnol. 1989, 31, 283-287. [CrossRef]

96. Sviridov, A.V.; Shushkova, T.V.; Zelenkova, N.F.; Vinokurova, N.G.; Morgunov, I.G.; Ermakova, I.T.; Leontievsky, A.A. Distribution of glyphosate and methylphosphonate catabolism systems in soil bacteria Ochrobactrum anthropi and Achromobacter sp. Appl. Microbiol. Biotechnol. 2012, 93, 787-796. [CrossRef]

97. Duke, S.O. Glyphosate degradation in glyphosate-resistant and -susceptible crops and weeds. J. Agric. Food Chem. 2011, 59, 5835-5841. [CrossRef]

98. Tazdaït, D.; Salah, R.; Grib, H.; Abdi, N.; Mameri, N. Kinetic study on biodegradation of glyphosate with unacclimated activated sludge. Int. J. Environ. Health Res. 2018, 28, 448-459. [CrossRef]

99. Edwards, V.H. The influence of high substrate concentrations on microbial kinetics. Biotechnol. Bioeng. 1970, 12, 679-712. [CrossRef]

100. Aiba, S.; Shoda, M.; Nagalani, M. Kinetics of product inhibition in alcohol fermentation. Biotechnol. Bioeng. 1968, 10, 845-864. [CrossRef]

101. Han, K.; Levenspiel, O. Extended Monod kinetics for substrate, product, and cell inhibition. Biotechnol. Bioeng. 1988, 32, 430-437. [CrossRef]

102. Luong, J.H.J. Generalization of Monod kinetics for analysis of growth data with substrate inhibition. Biotechnol. Bioeng. 1987, 29, 242-248. [CrossRef] [PubMed]

103. Tseng, M.M.C.; Wayman, M. Kinetics of yeast growth: Inhibition-threshold substrate concentrations. Can. J. Microbiol. 1975, 21, 994-1003. [CrossRef]

104. Yano, T.; Koga, S. Dynamic behavior of the chemostat subject to substrate inhibition. Biotechnol. Bioeng. 1969, 11, 139-153. [CrossRef]

105. Singh, S.; Kumar, V.; Singh, J. Kinetic study of the biodegradation of glyphosate by indigenous soil bacterial isolates in presence of humic acid, Fe(III) and Cu(II) ions. J. Environ. Chem. Eng. 2019, 7, 103098. [CrossRef]

106. Pipke, R.; Schulz, A.; Amrhein, N. Uptake of glycophosphate by an Arthrobacter sp. Appl. Environ. Microbiol. 1987, 53, 974-978. [CrossRef] [PubMed]

107. Hadi, F.; Mousavi, A.; Salmanian, A.H.; Akbari Noghabi, K. Glyphosate Tolerance in Transgenic Canola by a Modified Glyphosate Oxidoreductase (gox) Gene. Prog. Biol. Sci. 2012, 2, 50-58. [CrossRef]

108. Hove-Jensen, B.; Zechel, D.L.; Jochimsen, B. Utilization of Glyphosate as Phosphate Source: Biochemistry and Genetics of Bacterial Carbon-Phosphorus Lyase. Microbiol. Mol. Biol. Rev. 2014, 78, 176-197. [CrossRef]

109. Sviridov, A.V.; Shushkova, T.V.; Ermakova, I.T.; Ivanova, E.V.; Leontievsky, A.A. Glyphosate: Safety risks, biodegradation, and bioremediation. In Current Environmental Issues and Challenges; Springer: Dordrecht, The Netherlands, 2014; pp. 183-195, ISBN 9789401787772.

110. Villarreal-Chiu, J.F.; Quinn, J.P.; McGrath, J.W. The genes and enzymes of phosphonate metabolism by bacteria, and their distribution in the marine environment. Front. Microbiol. 2012, 3, 19. [CrossRef] [PubMed]

111. Chen, C.M.; Ye, Q.Z.; Zhu, Z.; Wanner, B.L.; Walsh, C.T. Molecular biology of carbon-phosphorus bond cleavage. Cloning and sequencing of the phn (psiD) genes involved in alkylphosphonate uptake and C-P lyase activity in Escherichia coli B. J. Biol. Chem. 1990, 265, 4461-4471.

112. Hove-Jensen, B.; McSorley, F.R.; Zechel, D.L. Physiological role of phnP-specified phosphoribosyl cyclic phosphodiesterase in catabolism of organophosphonic acids by the carbon-phosphorus lyase pathway. J. Am. Chem. Soc. 2011, 133, 3617-3624. [CrossRef]

113. Metcalf, W.W.; Wanner, B.L. Evidence for a fourteen-gene, phnC to phnP locus for phosphonate metabolism in Escherichia coli. Gene 1993, 129, 27-32. [CrossRef]

114. Hove-Jensen, B.; Rosenkrantz, T.J.; Zechel, D.L.; Willemoës, M. Accumulation of intermediates of the carbon-phosphorus lyase pathway for phosphonate degradation in phn mutants of Escherichia coli. J. Bacteriol. 2010, 192, 370-374. [CrossRef] [PubMed]

115. Santos-Beneit, F. The Pho regulon: A huge regulatory network in bacteria. Front. Microbiol. 2015, 6, 402. [CrossRef] [PubMed]

116. Adelowo, F.E.; Olu-Arotiowa, O.A.; Amuda, O.S. Biodegradation of glyphosate by fungi species. Adv. Biosci. Bioeng. 2014, 2, 104-118.

117. Arfarita, N.; Djuhari, D.; Prasetya, B.; Imai, T. The application of trichoderma viride strain frp 3 for biodegradation of glyphosate herbicide in contaminated land. J. Agric. Sci. 2016, 38, 275-281. [CrossRef] 
118. Carranza, C.S.; Barberis, C.L.; Chiacchiera, S.M.; Magnoli, C.E. Assessment of growth of Aspergillus spp. from agricultural soils in the presence of glyphosate. Rev. Argent. Microbiol. 2017, 49, 384-393. [CrossRef]

119. Gard, J.K.; Feng, P.C.C.; Hutton, W.C. Nuclear magnetic resonance tim ecourse studies of glyphosate metabolism by microbial soil isolates. Xenobiotica 1997, 27, 633-644. [CrossRef]

120. Liu, C.M.; McLean, P.A.; Sookdeo, C.C.; Cannon, F.C. Degradation of the herbicide glyphosate by members of the family Rhizobiaceae. Appl. Environ. Microbiol. 1991, 57, 1799-1804. [CrossRef] [PubMed]

121. Sharifi, Y.; Pourbabaei, A.A.; Javadi, A.; Abdolmohammad, M.H.; Saffari, M.; Morovvati, A. Biodegradation of glyphosate herbicide by Salinicoccus spp. isolated from Qom Hoze-soltan lake, Iran. Environ. Health Eng. Manag. J. 2015, 2, 31-36.

122. Shushkova, T.V.; Ermakova, I.T.; Sviridov, A.V.; Leontievsky, A.A. Biodegradation of glyphosate by soil bacteria: Optimization of cultivation and the method for active biomass storage. Microbiology 2012, 81, 44-50. [CrossRef]

123. Wackett, L.P.; Shames, S.L.; Venditti, C.P.; Walsh, C.T. Bacterial carbon-phosphorus lyase: Products, rates, and regulation of phosphonic and phosphinic acid metabolism. J. Bacteriol. 1987, 169, 710-717. [CrossRef] [PubMed]

124. Ajish, A.; Sukirtha, T.H. Biodegradation and Bioremediation of Glyphosate herbicide by Nocardia Mediterranie THS 1. Int. J. Sci. Res. 2020, 8, 34-36.

Publisher's Note: MDPI stays neutral with regard to jurisdictional claims in published maps and institutional affiliations.

(C) 2020 by the authors. Licensee MDPI, Basel, Switzerland. This article is an open access article distributed under the terms and conditions of the Creative Commons Attribution (CC BY) license (http://creativecommons.org/licenses/by/4.0/). 